\section{'Mountain Crest' Hybrid Tomato and its Parent, NC 1 rinEC}

\author{
R.G. Gardner \\ North Carolina State University, Raleigh, NC 27695-7609
}

Additional index words. Lycopersicon esculentum, rin gene, crimson $\left(\operatorname{og}^{c}\right)$ gene, extended shelf life, vine-ripe harvest

'Mountain Crest' is a fresh-market tomato (Lycopersicon esculentum Mill.) hybrid with extended shelf life resulting from the ripening inhibitor gene ( $\mathrm{rin}$ ) in heterozygous condition.

\section{Origin}

'Mountain Crest', the $\mathrm{F}_{1}$ hybrid of $\mathrm{NC}$ $84173 \mathrm{PVP} \times \mathrm{NC} 1 \mathrm{rinEC}$, resulted from a breeding program to develop an extendedshelf-life tomato cultivar adapted to vine-ripe production in North Carolina. Cultivars with extended shelflife based on use of the recessive

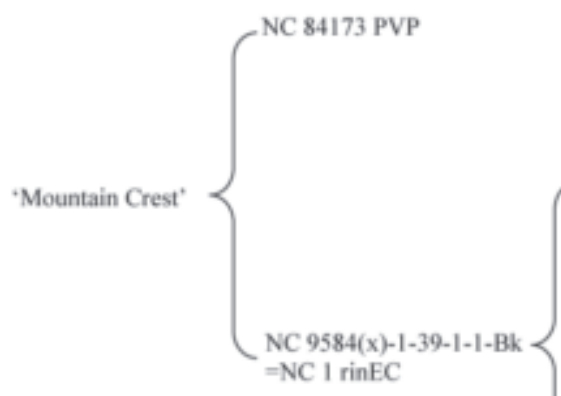

Received for publication 14 Mar. 2005. Accepted for publication 23 Nov. 2005. The use of trade names in this publication does not imply endorsement by the North Carolina Agricultural Research Service (NCARS) of the products names, nor criticism of similar ones not mentioned. This research was funded by the NCARS and the North Carolina Tomato Growers Association. at Fletcher, N.C. ripening inhibitor gene (rin) are now widely used for vine-ripe harvest in production areas outside the U.S. The rin gene in homozygous condition eliminates the production of ethylene in tomatoes thus inhibiting ripening of fruit. When used in the heterozygous condition in firm-fruited backgrounds, rin slows fruit ripening and softening resulting in extended shelf life. Rin extended-shelf-life hybrids are grown for vine-ripe harvest in Mexico during the winter for export to the U.S. and have competed strongly with Florida for markets. Florida ships primarily mature green harvested fruit subjected to ethylene to stimulate ripening. Although North Carolina growers have cultivars with adequate shelf life well adapted to vine-ripe production, some retail handlers of

Ingles-1 $(x)-5 A$

in $\mathrm{F}_{2}$ selection of

unknown cultivar tomatoes have indicated that they would prefer to market the extended-shelf-life rin hybrids on a year-round basis if such tomatoes were available because of less fruit loss (shrinkage) of these hybrids compared to normal ripening hybrids.

Commercial rin hybrid cultivars have not shown good adaptability to production in North Carolina in the summer. In addition to having defects in fruit quality characteristics such as fruit cracking and misshapen fruit, there are often problems with poor flavor and failure to attain a deep red color. Efforts over the last several years in the North Carolina tomato breeding program have focused on the development of improved rin hybrids with better color and flavor and adaptability to North Carolina growing conditions.

The rin gene used in developing $\mathrm{NC}$ 1rinEC, the male parent of 'Mountain Crest', was obtained from open-pollinated seed of an unknown $\mathrm{F}_{1}$ hybrid, fruit of which were purchased from a local supermarket. An $\mathrm{F}_{2}$ generation selection homozygous for the rin gene derived from this hybrid was crossed to NC 134G-2(94), a line with intense red color having the recessive crimson gene $\left(\mathrm{og}^{c}\right)$, (Fig. $1)$. In the $F_{2}$ generation from the resultant hybrid, NC 9584, selection was made for plants homozygous for both the rin and $\operatorname{og}^{c}$ genes. Among the plants in this $\mathrm{F}_{2}$ population, some were identified with more intense interior and exterior color than seen in the original rin plant obtained from selfing the unknown hybrid and

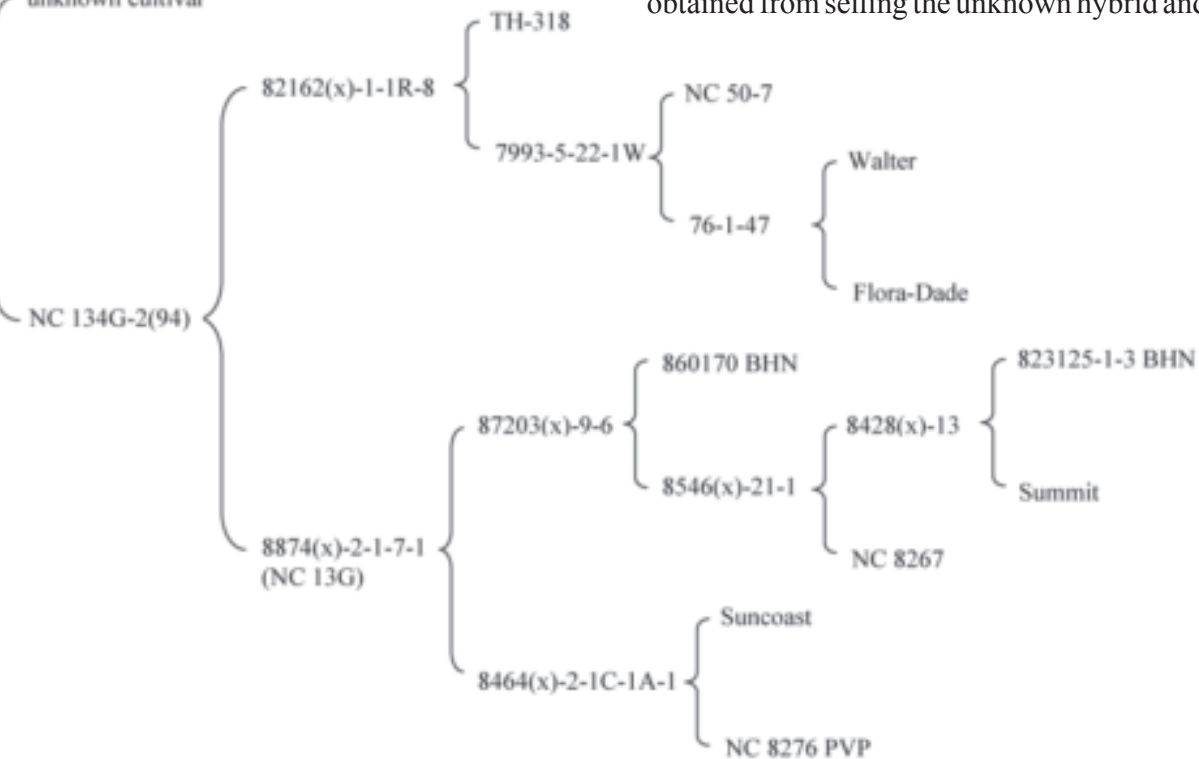

Fig. 1. Pedigrees of 'Mountain Crest' F1 hybrid tomato and its parent line, NC 1 rinEC.

Table 1. Comparison of 'Mountain Crest'” with standard tomato cultivars in staked, vine-ripe harvest trials

\begin{tabular}{lcccc}
\hline & \multicolumn{3}{c}{${\text { Yield }\left(\mathrm{t} \cdot \mathrm{ha}^{-1}\right)}^{2}$} \\
\cline { 2 - 4 } & & \multicolumn{2}{c}{ Total season } \\
\cline { 2 - 4 } Cultivar & $\begin{array}{c}\text { Early season } \\
\text { nongraded }\end{array}$ & Nongraded & $\begin{array}{c}\text { U.S. combination } \\
\text { grade }\end{array}$ & $\begin{array}{c}\text { Fruit } \\
\text { wt }(\mathrm{g})\end{array}$ \\
\hline Mountain Crest & 33 & 112 & 84 & 294 \\
Mountain Spring & 34 & 102 & 65 & 361 \\
Mountain Fresh & 26 & 114 & 89 & 317 \\
LSD $_{0.01}$ & 6 & NS & 16 & 21 \\
\hline
\end{tabular}

${ }^{\mathrm{z}}$ Based on eight replicated trials conducted over a 4-year period (1999-2002).

${ }^{y}$ First 2 weeks of harvest.

'U.S. No. 1 and No. 2 grade fruit. 
in other known lines with the rin gene. In numerous segregating populations from crosses with NC 1 rinEC, deep yellowish-orange exterior color of rin homozygous plants has been associated with a single, incompletely dominant gene distinct from $o g^{c}$. The combination of this gene with homozygous $\operatorname{og}^{c}$ in $\mathrm{rin}$ plants results in considerable red color scattered throughout the interlocular walls in addition to the more intense orange exterior color. The improved color in $\mathrm{NC} 1$ rinEC is likely derived from either 'Suncoast' (Scott et al, 1985), the source of $\operatorname{og}^{c}$ in NC1 rin EC, or NC 8276 PVP (Fig. 1). This improvement of color in homozygous rin lines is being termed rin enhanced color, abbreviated as rinEC. NC 1 rinEC was crossed with NC 84173 PVP (Gardner, 1992), a line with excellent combining ability, which is used as a parent in several North Carolina Sate University-named hybrids and in several commercial seed company hybrids. The resultant hybrid was tested as NC 98100 before its naming and release in 2002.

\section{Description}

'Mountain Crest' was rated outstanding in observational plots in 1998 at Fletcher, N.C., and has been tested in replicated trials at Fletcher since 1999. In eight replicated trials conducted over a 4-year period, 'Mountain Crest' produced as well as 'Mountain Fresh' (Gardner, 1999) in yield of U.S. combination grade(U.S. no. 1+U.S. no.2 fruit) and exceeded 'Mountain Spring' in yield of U.S. combination grade fruit (Table 1). 'Mountain Crest' was as early as 'Mountain Spring' in maturity and earlier than 'Mountain Fresh'. Average fruit weight of 'Mountain Crest' was less than that for 'Mountain Spring' and 'Mountain Fresh' but still acceptable (Table 1).

Fruit of 'Mountain Crest' develop deep red color and are very firm in the fully ripened stage. Flavor of 'Mountain Crest', based on numerous subjective ratings, is equivalent to that of 'Mountain Spring'. Like other hybrids with the rin gene, fruit texture of 'Mountain Crest' remains crisp and does not soften when ripe as does the texture of normal hybrids. Immature fruit have a glossy, uniform green color $(u)$. Fruit pedicels are jointed. The fruit are deep oblate to flattened globe in shape with generally smooth blossom end scars and have good resistance to fruit cracking and weather check. 'Mountain Crest' has performed well in many observational trials in research station and grower fields throughout the mountains and piedmont of North Carolina and in spring plantings in the coastal area of South Carolina. 'Mountain Crest' was received favorably by growers who produced it in large-scale trial plantings in 2001-03 and in commercial field production in 2004.

'Mountain Crest' has a vigorous determinate plant $(s p)$ similar in height to that of 'Mountain Fresh' when staked. Foliage has slight leaf curl and provides adequate, but not dense, cover for fruit protection. 'Mountain Crest' has resistance (Ve gene) to Verticillium dahliae Kleb. and resistance ( $I$ and $I-2$ genes) to races 1 and 2 of Fusarium oxysporum f.sp. lycopersici (Sacc.) Snyd. and Hans.

NC 1 rinEC has a vigorous determinate plant with moderately heavy foliage, which exhibits slight leaf curl. Fruit are uniform ripening $(u)$ with jointed fruit pedicels and are deep oblate to flattened globe in shape. Fruit of NC 1 rinEC develop a deep orange exterior color when mature. The fruit interior has red streaks scattered throughout the flesh. A color image of $\mathrm{NC} 1$ rinEC can be viewed at the website www.ces.ncsu.edu/fletcher/programs/tomato. Fruit of NC 1 rinEC have smooth blossom end scars and have shown good resistance to fruit cracking and weather check. It has the I-2 gene for resistance to race 2 of fusarium wilt. NC 1 rinEC has not been tested for other disease resistances nor has it been harvested to measure yield, fruit grade, or fruit size. It has been observed in many observational plantings to produce a heavy set of uniformly large fruit.

\section{Use}

'Mountain Crest' is the first extended-shelflife cultivar with the rin gene released from the North Carolina State University fresh-market tomato breeding program. It will provide growers in North Carolina and other production areas with similar growing conditions an adapted rin heterozygous cultivar for customers who want this type of tomato. NC 1 rinEC is intended for use as a parent in the production of $F_{1}$ hybrids and as a source of improved color for further breeding with rin tomatoes.

\section{Availability}

'Mountain Crest' was released on an exclusive basis for seed production and sales to Sunseeds (now Nunhems) and commercial seed have been available since 2004. Small samples of 'Mountain Crest' and NC 1 rinEC are available from R.G. Gardner, MHCREC, 455 Research Drive, Fletcher, NC 28732. Recipients of NC 1 rinEC will be required to sign a seed transfer agreement before receiving seed.

\section{Literature Cited}

Gardner, R.G. 1992. 'Mountain Spring' tomato; NC 8276 and NC 84173 tomato breeding lines. HortScience 27:1233-1234.

Gardner, R.G. 1999. NC 109 tomato breeding line. 'Mountain Fresh' $F_{1}$ hybrid. HortScience 35:941-942.

Scott, J.W., P.J. Everett, H.H. Bryan, D.D. Gull, T.K. Howe, P.J. Stofella, and R.B. Volin. 1985. Suncoast: A large-fruited home garden tomato. Fla. Agr. Expt. Sta. Circ. S-322. 